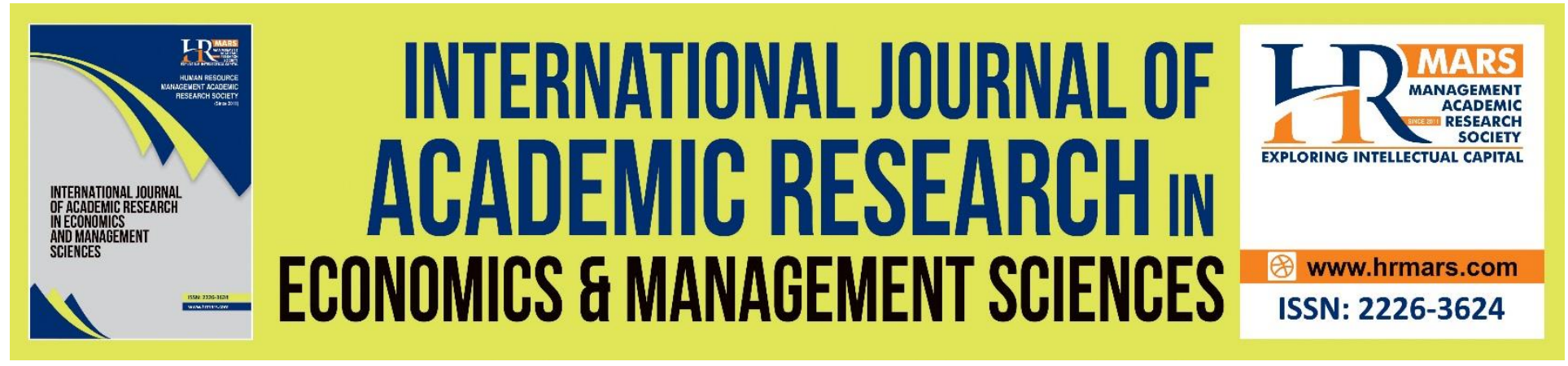

\title{
The Development of Safety Behavior: A 30-Year Review
}

\section{Rusyda, H. M, Siti Fardaniah Abdul Aziz}

To Link this Article: http://dx.doi.org/10.6007/IJAREMS/v10-i1/9212

DOI:10.6007/IJAREMS/v10-i1/9212

Received: 01 January 2021, Revised: 29 January 2021, Accepted: 24 February 2021

Published Online: 21 March 2021

In-Text Citation: (Rusyda \& Aziz, 2021)

To Cite this Article: Rusyda, H. M., \& Aziz, S. F. A. (2021). The Development of Safety Behavior: A 30-Year Review. International Journal of Academic Research in Economics and Managment and Sciences, 10(1), 46-71.

Copyright: (C) 2021 The Author(s)

Published by Human Resource Management Academic Research Society (www.hrmars.com)

This article is published under the Creative Commons Attribution (CC BY 4.0) license. Anyone may reproduce, distribute, translate and create derivative works of this article (for both commercial and non-commercial purposes), subject to full attribution to the original publication and authors. The full terms of this license may be seen at: http://creativecommons.org/licences/by/4.0/legalcode

Vol. 10, No. 1, 2021, Pg. 46 - 71

http://hrmars.com/index.php/pages/detail/IJAREMS

JOURNAL HOMEPAGE

Full Terms \& Conditions of access and use can be found at http://hrmars.com/index.php/pages/detail/publication-ethics 


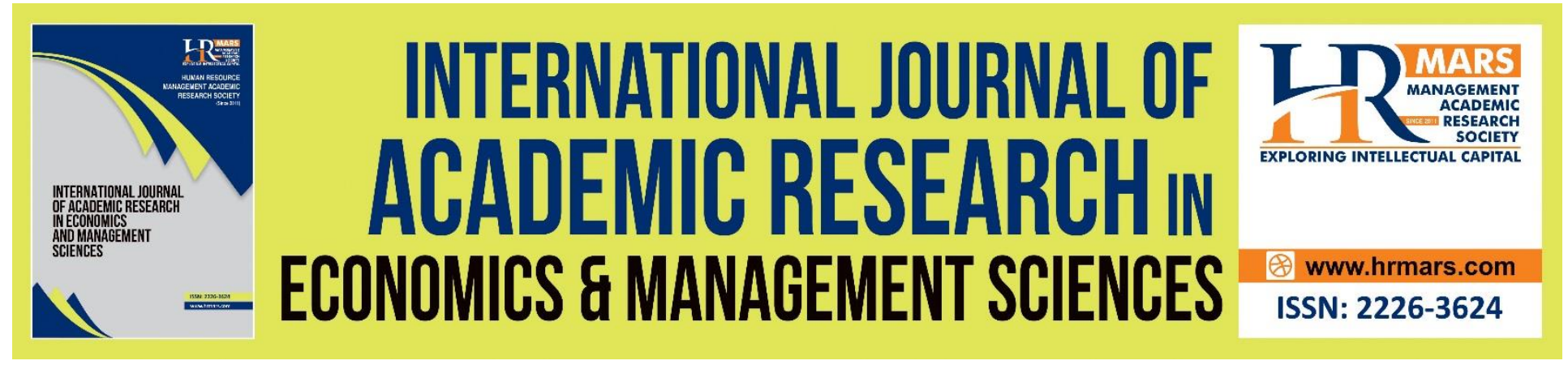

\title{
The Development of Safety Behavior: A 30-Year Review
}

\author{
Rusyda, H. M, Siti Fardaniah Abdul Aziz \\ Human Development Program, Center for Research in Psychology and Human Well-Being, \\ Faculty of Social Sciences and Humanities, Universiti Kebangsaan Malaysia \\ Email: daniah@ukm.my
}

\begin{abstract}
In the area of safety at work, safety behavior is becoming a significant concern. Safety behavior is often used interchangeably with safety outcomes, whether positive or negative; the latter being represented by accidents and the financial losses that they entail. Several investigations have tried to reveal a connection between safety policy and safety behavior. Safety behavior is a demonstration of safety policy and the processes employed to avoid adverse safety implications. Traditionally, employees have observed safety processes that follow the safety policy. Recently, however, employees have become effective agents of that policy, by suggesting general enhancements of organizational safety. This modern approach relies strongly on the behavior, awareness, and understanding of employee safety. This standpoint then contributes to another element that scrutinizes a bottom-up strategy to enhance workplace safety. The bottom-up strategy is seen as more versatile but calls for a certain amount of autonomy and emotional ability. With this approach, the obligation to maintain workplace safety is effectively delegated to both employees and workers, each playing a significant role. In this paper, we will demonstrate the relationship between climate and safety behavior. Also, we will discuss the evolution of traditional safety behavior towards the current level of safety participation and proactive safety behavior.
\end{abstract}

Keywords: Proactive Safety Behavior, Safety Behavior, Safety Climate

\section{Introduction}

The most significant industrial disasters have influenced the safety of the workforce for some 30 years since the original climate safety studies. The tragedies of both Bhopal and Chernobyl were attributable to workplace safety offenses which prompted countless social scientists to explore further the functions of senior leadership in formulating strategies to avoid accidents. To guarantee that workers are following all safety processes and preventing unwanted interruptions in their work, the workplace safety environment must emphasize management's function in creating and implementing the safety strategy. 
The safety climate is strongly affected by the organizational climate. Safety climate refers to "shared perceptions concerning safety policies, procedures, and practices" (Zohar, 2011, p. 143 ) in an organizational setting. Recognition within the organization of the need for safety has developed a holistic strategy to handle and monitor its advancement carefully. Workplace accidents and accident reports are the primary sources of data with which to avoid unfortunate events and significant loss. To be precise, organization and governance are accountable for safeguarding the safety of the workplace. Hence, organizational leaders' functions are crucial in encouraging safety understanding and procedures among subordinates, by offering extrinsic motivation or rewarding healthy safety behavior.

The importance of the safety climate in improving safety for individuals at work and the question of how that climate operates has been unsure until recently. Although there is a substantial set of studies focusing on safety-related factors, the embedded constructs are sparse on aspects of organizational climate, safety climate, safety behavior, and safety outcomes.

\section{Understanding the Relevance of Climate and Safety Behavior}

There are different interpretations of the organizational climate. Tyagi (1982) defines organizational climate as a situationally-determined, psychological process concerning attitudes and performance, while Schneider et al. $(2013 ; 1989)$ calls it a behavioral orientation to policies, practices, and procedures. Others define organizational climate as global perceptions regarding objective organizational situations (Campbell, 1992; Churchill, Ford, \& Walker, 1976). The organizational climate is dynamic, and it fluctuates according to policy and operationallymanaged preferences (Joyce, Slocum, Slocum, \& Joyce, 1982; M. Patterson, Warr, \& West, 2004) which can change the way employees perceive and interact with their organization's existing procedures (Denison, 1996; Hellriegel \& Slocum, 1973a).

The role of organizational climate in affecting behavior is observed through a perception process that consists of three dimensions, namely stimuli, restrictions of undesirable behavior, and also rewards and punishments (Qualls \& Puto, 1989). Stimuli are strongly associated with the role of leadership (Koene, Vogelaar, \& Soeters, 2002; Rogg, Schmidt, Shull, \& Schmitt, 2001) which encourages employees to follow certain procedures. The most important stimulus was in the area of transformation management (Dust, Resick, Margolis, Mawritz, \& Greenbaum, 2018; Glisson \& Hemmelgarn, 1998; Toulson \& Smith, 1994), which is an important predictor in an organization, owing to the significance of aspiration and the drive to attain efficiency. The organizational policy is often used to clarify the importance of maintaining high standards of conduct (Clarke, Sloane \& Aiken, 2002; Verbeke, Volgering, \& Hessels, 2002) that are compatible with good organizational practices.

Organizational climate attempts to achieve high-level performance, which then impacts favorably upon four distinct categories, namely economics (as shown by enhanced profit and productivity) (Aarons \& Sawitzky, 2006; Montes, Moreno, \& Fernández, 2004); technology (new outputs); commercial advantage (products or industrial specialization) and social effects (satisfied customers) (Patterson et al., 2005). Tangible results are the most common factor in understanding organizational performance within organizational studies (Dickson, Resick, \& Hanges, 2006; Patterson, Warr, \& West, 2004). 


\section{Safety Climate}

Safety climate refers to the mutual knowledge and perception of safety among employees within their organization that warrants particular rules governing certain behaviors (Diaz \& Cabrera, 1997; Wang, Sun, Du, \& Wang, 2018; Yang, Spector, Chang, Gallant-Roman, \& Powell, 2012; Zohar, 1980).

Safety climate is a subgroup of organizational climate identified as one of the leading research in workplace safety. Industrial and organizational psychology divides safety climate into two separate classifications: the climate of safety and the climate of psychosocial safety (Dormann \& Zapf, 1999; Tuckey, Dollard, Saebel, \& Berry, 2010; Zapf, Dormann, \& Frese, 1996). Safety climate is based upon an organization's perceived value of safety (Arnol, 2018; Bahari \& Clarke, 2013; Griffin \& Neal, 2000; Niskanen, 1994), whereas the climate of psychosocial safety focuses on psychological health and well-being and is exclusively linked to a person's psychological condition (Becher, Dollard, Smith, \& Li, 2018; Hall, Dollard, \& Coward, 2018).

However, in addition to Zohar's safety climate definition, other scales have been created to measure safety for particular industries (Ghahramani \& Khalkhali, 2015; Mearns, Whitaker, \& Flin, 2001; Nel \& Visitor, 1998; Niskanen, 1994) or for particular nations (Becher et al., 2018; Hutchinson et al., 2006; Kines et al., 2011). Nevertheless, Zohar's definition of safety climate is that most commonly adopted by studies globally, based on meta-analysis findings (Beus, McCord, \& Zohar, 2016).

For the past 40 years, safety climate has been researched from three standpoints:

1. Safety measurement validation (Brown \& Holmes, 1986; Cooper \& Phillips, 2004a; Huang et al., 2013; Johnson, 2007; Zohar, 1980b).

2. Safety climate as a precedent for performance (Andrew, Neal, \& Griffin, 2000; Blair, 2003; Griffin \& Neal, 2000; Grill, Pousette, Nielsen, Grytnes, \& Törner, 2017; Hu et al., 2018; Díaz \& Cabrera, 1997; Flin, Burns, Mearns, Yule, \& Robertson, 2006; Oah, Na, \& Moon, 2018; Seo, Torabi, Blair, \& Ellis, 2004; Singer et al., 2007).

3. Safety climate as an outcome. Safety climate perspective holds employers responsible for safety in the working environment (Griffin \& Hu, 2013; Griffin \& Neal, 2000; Zohar \& Erev, 2006; Zohar \& Luria, 2005).

Eight specific dimensions are associated with employees' collective perceptions of the organizational safety climate (Jiang, Lavaysse, \& Probst, 2018; Singer, Lin, Falwell, Gaba, \& Baker, 2009):

1. Perceived importance of safety training programs.

2. Perceived management attitudes towards safety.

3. Perceived effects of safe conduct on promotion.

4. Perceived level of risk at work.

5. Perceived effects of the required pace of work on safety.

6. Perceived status of the safety officer.

7. Perceived effects of safe conduct on social status.

8. Perceived status of the safety committee.

These eight factors were identified by factor analysis (Zohar, 1980, 2002, 2008), and a general organizational climate that includes communication, values, managerial culture, and safety should also provide a safety assessment method (Zohar, 1980). Following that factor analysis, nine redundant items were removed from the initial safety climate questionnaire, and 
40 items were kept. Following this research on safety climate, workplace-safety studies led to the assertion that human error is not the primary cause of workplace accidents (Neal, Griffin, \& Hart, 2000).

Although Zohar's safety climate study was among the first of its kind, it has been reevaluated and criticized by other researchers. Brown and Holmes (1986), authors of the first study to re-evaluate the safety climate, researched an American sample using a safety climate measure. This validation study was conducted to define whether the safety climate scale can be used for other samples. Brown and Holmes, however, divided the sample into two categories: pre-traumatic (without workplace accident experience) and post-traumatic (with workplace accident experience) (Cabrera-Nguyen, 2010; Díaz \& Cabrera, 1997; Eagly, 1992) to determine whether the proposed safety climate measure is universal and can be used for both accident/injury and non-accident/injury cohorts.

The findings indicate that the eight-factor climate safety measure reduced the threefactor climate safety measure (Michael, Evans, Jansen, \& Haight, 2005). The results show that only three factors were accepted; worker insight into how management was concerned with their well-being, an understanding of the employees' active management in addressing this issue, and the physical risk perception of employees (Pousette, Larsson, \& Törner, 2008; Tholén, Pousette, \& Törner, 2013). Brown and Holmes also found that Zohar's' perceived safety management attitudes measure management behavior, not attitude, and so they replaced them with the second factor in their research; employee perception of how active management responded to this concern.

The newly-improved safety climate measure has an acceptable measurement model with CFI=.94 (Baba, Tourigny, Wang, \& Liu, 2009; Bertolino, Truxillo, \& Fraccaroli, 2011). Following the Brown and Holmes study, extensive validation research was undertaken to investigate the universality of safety climate measures (e.g., Huang et al., 2016; Johnson, 2007; Kines et al., 2010).

However, one important feature of safety climate studies is that they include multi-level modeling research to understand the perception process at the group level (Howardson, Karim, \& Horn, 2017; Idris, Dollard, \& Yulita, 2014; Petrou, Demerouti, Peeters, Schaufeli, \& Hetland, 2012; Zohar, 2008). This is consistent with climate being seen as "a shared perception" (Dickson, Smith, Grojean, \& Ehrhart, 2001; Idris, Dollard, Coward, \& Dormann, 2012; Kines et al., 2011). Studies should be conducted on at least two levels to measure mutual perception; individual level and group level (Yin, Xing, Li, \& Guo, 2017; Yu, de Ruyter, Patterson, \& Chen, 2018) to determine the impact of the safety climate. The latter is only valid when the perception is mutually agreeable and confirmed by the employees, as mentioned at the beginning of this article.

Although safety climate is studied for its role in occupational accidents (Griffin et al., 2014; H. Liu et al., 2010; Morrow et al., 2010), self-reported injuries (Kolarcik, Geckova, Orosova, van Dijk, \& Reijneveld, 2009; Probst, 2004; Vinodkumar \& Bhasi, 2010), job demands and workloads (Donoso, Demerouti, Garrosa Hernández, Moreno-Jiménez, \& Carmona Cobo, 2015; Ho \& Astakhova, 2018; Javaid et al., 2018; Niskanen, 1994; Odoardi, 2015), there has been little study of the interaction between safety climate and safety behavior. 


\section{Safety Behavior: Definitions, Constructs, and Conceptualizations}

Attempts were made to comprehend the relationship between safety climate and safety behavior when scientists started exploring the connection between the two factors. Zohar endeavored to find a connection between his safety climate measurement and behavior and discovered that safety climate is linked to safety behavior through a collective safety climate (DeJoy, Schaffer, Wilson, Vandenberg, \& Butts, 2004; Zohar, 2008).

This group safety climate has a more logical explanation in understanding the said relationship because individual employees are more inclined to follow the group's safety behavior (Zhang, Chen, Li, Wu, \& Skibniewski, 2018). Moreover, employees seldom feel the connection with the organizational safety climate, especially management's commitment to safety, due to the power structure and power distance (Purwanto, 2018; Singh \& Verma, 2018).

Glendon and Litherland (2001) created a behavioral measure of safety climate with their Safety Climate Questionnaire (SCQ) covering 40 factors. In doing so, they moved away from Zohar's safety climate definition, which is based exclusively on employee expectations of the organizational approach to safety (Jones, Momin, Good, Shea, \& Patric, 2009; Mackinnon \& Sherry, 2012).

These behaviorally-anchored scales have been investigated to see whether safety behavior is internally induced (by individual employees) or externally induced (by their working environment). It also examines the extent to which human error affects the number of accidents and injuries (Evans, Glendon, \& Creed, 2007; Glendon \& Stanton, 2000). The scale for SCQ is verbally anchored, in that the questions must be answered with "never", "sometimes", or "always" (Didla, Mearns, \& Flin, 2009; Grill et al., 2018; Hystad \& Bye, 2013). However, the relationship between safety climate and safety behavior still uncertain and insignificant.

More research was conducted to identify the connection between safety climate and safety behavior, using a modified version of Zohar's safety climate definition and peers' observation of safe/unsafe work behavior (Cooper \& Phillips, 2004b). The management attitude scale was modified, and management actions regarding safety were reintroduced. Several employees were recruited and trained to observe any good conduct or misconduct by peers or leaders, as part of the measurement of safety behavior (Graen \& Uhl-Bien, 1995; Hofmann, Morgeson, \& Gerras, 2003). The relationship between safety climate and safety behavior, however, was limited and inconsistent.

Several problems have been identified based on these studies. First, the conceptualization of safety behavior is uncertain. Second, because the relationship between safety climate and safety behavior appears weak to the point of being meaningless, there is another hypothesis of a proximal-distal relationship between safety climate and safety behavior (Kines et al., 2010; Zhao \& Peterson, 2017). Research by Griffin and Neal (2000) aimed to enhance an understanding of this relationship.

Their work began with redefinition and re-conceptualization of safety behavior. They also explored the effects of additional individual determinants such as attitudes, skills, and motivation, as antecedents of safety behavior and organizational safety climate, along with the effects of leadership and personality as distal antecedents (Clarke et al., 2016; Kinman \& Jones, 2005). 


\section{Safe and unsafe behavior}

Safety behavior is a simple term, referring to a series of actions designed to reduce potential accidents (Meliá, Mearns, Silva, \& Lima, 2008; Shamsuddin, Ani, Ismail, \& Ibrahim, 2015). While unsafe behavior refers to actions that are more likely to increase risk and accidents (Dester \& Blockley, 1995), discussions about unsafe behavior often presume that an individual is uncertain as to what constitutes safe and unsafe behavior. This could be due to limited understanding or ignorance of safety processes (Aytac \& Dursun, 2011) when forced to perform work in an unsafe manner due to contextual constraints (Gonçalves, da Silva, Lima, \& Meliá, 2008; Nordfjærn, Jorgensen, \& Rundmo, 2011). Similarly, individual characteristics like inattention, demotivation, and carelessness (Reason, 2016) may result in events that are potentially catastrophic (Zohar \& Erev, 2006).

Safe and unsafe behavior in the behavioral rating process (Seppälä et al., 2017) are crucial in the inventory construction. Behavioral-based safety is a bottom-up approach to identifying and understanding safe and unsafe behavior of different types (Shamsuddin et al., 2015). This procedure is well-known in the Behavior-Based Safety program that highlighted the importance of self, peer, and subordinate review of safe and unsafe behavior in a specific organization (Choudhry, 2014). The data is treated as the basic information needed for an employer to develop the best intervention program to improve security at work (Chakrabarty, 2018).

Behavior-based safety attracted widespread attention when first introduced as a new form of safety-management program that focused upon employees (Ismail, 2014). It has since attracted criticism, however, and stands accused of being a new form of manipulation (Folkman, 2018; Spigener, Amato, \& Craig, 2002) by employers keen to sidestep their responsibility for maintaining workplace safety (Skowron-Grabowska \& Sobociński, 2018).

One major flaw in a Behavior-Based Safety program is the under-reporting of accidents and injuries (Scott, 2001) caused by fear of punishment for failing to perform tasks in a safe manner (Cooper, 2009). Apart from that, it has been praised as one of the best methods of identifying types of safe behavior while addressing unsafe behavior for a safer environment (Depasquale \& Geller, 1999).

\section{The Development of Safety Behavior: Safety Behavior as Safety Performance}

The definition of safety behavior is a comprehensive series of concepts based on the view of clinical psychology, industrial psychology, organizational psychology, and social learning. From the perspective of social learning, the safety behavior of an individual is explained through an analysis of how safe behavior is formed by environmental learning (Golkar, Castro, \& Olsson, 2015). A further path in understanding safety behavior is to note the role played by fear. Fear is a condition in which people are more aware of unfortunate consequences and they will take all possible steps to avoid encountering this condition (Ahn, Lee, and Steel, 2013). Safety behavior stems essentially from social learning, which emphasizes the importance of 'carrot and stick approach' to maintain safety. An organization can learn much from its members, be they an employee's peers or leaders (Newaz et al., 2010).

Clinical psychology refers to explicit or implicit safety behaviors, under exact circumstances, to make efforts to prevent formidable results (Salkovskis et al., 1999; Salkovskis, 1991). The concept was derived from the clinical psychology research area that uses the same concept to treat patients with anxiety or other psychological illness (Radomsky, 2008; 
Vansteenwegen et al., 2005). The therapy, which is also connected with cognitive behavior therapy (CBT, 1999; Morgan \& Raffle, 1999), is a prevention method that employs several techniques to decrease clients' potential stress.

From an industrial and psychological point of view, safety behavior is solely linked to compliance with policies and procedures (Toppazzini \& Wiener, 2017) to prevent accidents and injuries to oneself or others (Adilla et al., 2017; Nahrgang, Morgeson, \& Hofmann, 2011) as well as to maintain physical and psychological health (Gonçalves et al., 2008). Safety behavior is known as one of the most critical elements in ensuring the prevention of accidents and injuries (Agnew, Flin, \& Mearns, 2013). If it fails to do so, the result is the loss of valuable workplace resources (Shamsuddin et al., 2015).

To be precise, safety behavior, which is measurable based on a safe and unsafe inventory in the organization (Uehli et al., 2014) is a crucial issue (Berberoglu, 2018) that has a positive or negative impact, depending on the extent to which it is embraced by an organization's members (Beus et al., 2010; McSween \& Moran, 2017), in the interests of the organization as a whole. In the next section, further explanations of safety conduct will be discussed.

Based on Kurt Lewis's field theory, safety behavior is a performance that arises from the interaction between a person and his or her environment (Blair, 2003; Du et al., 2018; Lewin, 1943). Safety behavior is much more observable, quantifiable, and tangible (Råheim et al., 2016; Uehli et al., 2014) compared to behavior with a broader, more subjective context (Blair, 2003). Safety performance (behavior) is often mistakenly seen as similar to safety outcomes. Although both concepts are connected, safety performance differs from a theoretical perspective (Griffin et al., 2014; Singer et al., 2007).

There are two outcomes in safety: positive outcomes and negative outcomes and the greatest predictors for safety behaviors are motive and skills (McCoy, Roy, \& Sirkman, 2013; Panatik et al., 2012). Safety behavior can be divided into three categories; safety compliance, safety participation, and safety initiative. Safety compliance and safety participation were drawn from the performance model of prosocial organizational behavior and organizational citizenship behavior (Motowildo, Borman, \& Schmit, 1997; Organ, 1997; Van Scotter, Motowidlo, \& Cross, 2000). Safety initiative, on the other hand, stemmed from the proactivity construct that elaborated on anticipatory actions in safety behavior (Curcuruto et al., 2015; Matteo Curcuruto \& Griffin, 2018).

\section{The Conventional Stage: Safety Compliance}

Compliance with desirable safety behavior, such as procedural compliance or using personal protective devices, plays its part in ensuring personal safety (Ersen \& Bilgiç, 2018). It refers to the assumption that individuals must develop a routine according to labor safety standards that includes following a formal set of tasks which has a significant impact on the safety results of the organization (McCoy, Roy, \& Sirkman, 2013). Safety compliance is related to task performance that relies upon employees fulfilling expectations to follow prescribed procedures that are task-oriented and associated with the employees' job descriptions (Gonçalves et al., 2008). The conceptualization of safety compliance is quite particular; it relates to observable and measurable skills and abilities (Diaz-Vilela et al., 2015).

An employee safety program should be focused on the employer's safety climate and strategy, and leaders are accountable for motivating employees to follow formal directions (Kines 
et al., 2010). However, safety compliance assumes that the employees' function is restricted and should be about adhering to safety strategy and its processes (Law et al., 2011). Identifying safety standards and personal safety behaviors that play a major role in compliance with safety regulations arises from the safe and unsafe behavior inventory discussed in the previous section (Silva, Lima, \& Baptista, 2004; Warmerdam et al., 2018).

Safety compliance depends on whether the employees performed the task in a safe manner, emphasizing the importance of mental capacity in understanding and processing instructions to meet all demands (Locke, Frederick, Lee, \& Bobko, 1984; Spitzmuller, Sin, Howe, \& Fatimah, 2015). Also known as passivity, safety compliance should be seen as a process that begins with goal-setting development (Greenglass \& Fiksenbaum, 2009). To ensure successful performance, employers stress the importance of maintaining safety behavior and accident prevention as their default objective. The employees must, therefore, follow safety procedures to achieve objectives (Locke \& Latham, 1990; Rolfe, 2006; Rotundo \& Sackett, 2005).

However, understanding and internalizing a predetermined goal is insufficient without the attitude and trust that follows and implements procedures. Safety compliance that began with understanding the predetermined goal is usually followed by an appropriate attitude toward the idea (Watts et al., 2010). Attitude is a positive or negative response to a predetermined goal, depending on the effects of other accompanying factors, such as learning experience, knowledge, and reinforcement (Kaya, Barsbay, \& Karabulut, 2010).

Studies have shown that age and work experience have an impact on safety attitudes in adverse situations. Older employees tend to have negative attitudes towards safety compliance due to their risk-taking propensity, assuming that their length of service and work experience have provided them with better skills for anticipating accidents (Heyer et al., 1992; Warr, 1990). Self-confidence, a motivational mechanism also known as self-efficacy, refers to the employees' belief that the goal is achievable and brings positive outcomes for them and others (de Jonge et al., 2004). Self-confidence in safety is associated with people's judgment of their capabilities to coordinate and implement a series of activities in achieving a designated safety behavior (KatzNavon, Naveh, \& Stern, 2007). The relationship between attitude and self-confidence is strong and significant, which explains why a positive safety attitude will increase self-confidence in safety compliance (Conchie, 2013; Dzewaltowski, Noble, \& Shaw, 1990; Haas et al., 2019).

\section{The people-oriented stage: Safety participation}

Contextual performance is defined as a behavioral construct that goes beyond the required task's performance (Van Scotter \& Motowidlo, 1996). Drawing from the contextual approach to performance, safety participation is referred to as helping peers and leaders to address issues related to occupational safety (Clissold, Buttigieg, \& Cieri, 2012), or volunteering for activities that promote workplace safety. These could include attending safety meetings, voicing ideas, or raising concerns to improve workplace safety (Liu, Zhao, Jiang, \& Li, 2015) and not just personal safety (Penner, 2002; Zhang \& Wu, 2014). Safety participation is teamwork, and social effort has a role to play in promoting the organizational culture (Motowildo et al., 1997), and persuading employees to offer a positive commitment to complying with organizational rules (Tutar, Altinoz, \& Cakiroglu, 2011).

Safety participation is often linked to extra-role behavior rather than to other organizational behavioral patterns such as prosocial behavior or organizational citizenship 
behavior (Belschak \& Den Hartog, 2010; Schmitt, Den Hartog, \& Belschak, 2016). The additional role is related to helping people and challenging the safety performance system (Clayton, 2015) by actions such as "whistleblowing" (Bjørkelo, Einarsen, \& Matthiesen, 2010).

In terms of safety participation, whistleblowing is crucial because employees need to be confident in expressing safety concerns, even if to do so is destructive, either to them or to their social relationships (Hu et al., 2018). This action aims to promote a supportive, safe environment for the whole organization (Grant, 2013).

The distinguishing factor between safety compliance and safety participation is the concept of interpersonal and intrapersonal relationship (Judge, LePine, \& Rich, 2006). Safety compliance is specifically related to personal safety and is observed from a cognitive and internalized perspective (Welbourne, Johnson, \& Erez, 1997). Safety participation, on the other hand, is strengthened through the relationship between an organization's members and is more practical across the organizational hierarchy (Greenslade \& Jimmieson, 2007). Safety participation's core principles include helping other people, such as team members or leaders, to achieve the predetermined goal (Mohammed, Mathieu, Bartlett, \& Wiley, 2011). Helping behavior is the paramount factor behind effective work in team safety settings (O'Connell, Hartman, McDaniel, Grubb, \& Lawrence, 2007). Helpfulness is neither reward-oriented nor required by the formal job description (Mersman \& Donaldson, 2000), it is absolute voluntarily effort.

Psychological safety, such as trust between members is vital to ensure that safety participation is achieved (Aryee, Sun, Chen, \& Debrah, 2008). Trust is one of the main factors in nurturing safety participation and bringing employees and their leaders to work together (Alaarj, Mohamed, Salwa, \& Bustamam, 2017; Triplett \& Loh, 2018) to improve and contribute to the organization's safety environment (Neto, Silva, \& Ferreira, 2018). Participants must demonstrate and guarantee that they are both credible and willing to assist the safety suggestions of other participants (Brown, Treviño, \& Harrison 2005).

Leaders have a greater role in building trust and promoting security by preserving a secure, favorable and supportive environment in which the organization's members can interact (Lahuis, Martin, \& Avis, 2005), and by encouraging and welcoming proposals to improve safety at work (Carlson et al., 2008).

\section{The Proactive Stage: Safety initiative}

The safety initiative is traditionally conceptualized as a safeguard effort begun at seniormanagement level to improve and maintain safety at work (Dorn \& Brown, 2003; Hoe, 2014). The managerial level is answerable to either a regulatory body, such as the National Institute for Occupational Safety and Health (NIOSH), or to their employers (Cunningham \& Jacobson, 2018).

Safety initiatives are frequently implemented as a reactive or passive effort by employers to maintain safety or to reduce losses due to accidents and injuries (McFadden, Henagan, \& Gowen III, 2009). Safety initiatives are based on the concept of a safety culture that emphasizes the responsibility of the government and employers to provide a safe working environment and promote safety and health in the workplace (Ali, Abdullah, \& Subramaniam, 2009; Parizad et al., 2018).

The essence of the safety initiative is to build awareness, to offer knowledge and expertise, and to serve as a platform for discussions of safety. The components of safety 
initiatives include safety policies, safety committees, safety training sessions, and safety meetings (Hoonakker et al., 2005) and are largely aligned with the compliance with safety initiatives discussed earlier.

However, the safety initiative has recently been redefined and observed from a different perspective; namely improving the general work environment (Matteo Curcuruto, Parker, \& Griffin, 2019). Emerging from the constructs of proactive behavior, safety initiatives are referred to as anticipatory, self-initiated and change-oriented efforts to participate in safety (Matteo Curcuruto \& Griffin, 2018) and are often carried out at a personal level (Low, Man, \& Chan, 2018; Wang, Sun, Du, \& Wang, 2018).

The safety initiative is now being constructed as a new form of safety behavior; one that follows a bottom-up approach that differs from safety participation from the individuals and futurefocused approach (Haas et al., 2019).

\section{Conclusion}

A safe working environment is important for both employees and employers. Avoiding negative outcomes such as accidents, injuries, and the serious financial losses they can entail for those involved should be an organization's principal focus, alongside maintaining its employees' well-being. Studies, however, have shown that policies without enforcement and evaluation are fruitless and often lead to more critical issues affecting organizational sustainability.

Employing the conventional lens, safety behavior is perceived as the product of a comprehensive safety and enforcement policy. Employees are recognized as a unit that has a role to play in complying with the rules established by the behavioral change organization. Although the stand is commendable, other internal factors like individual differences must be examined and acknowledged. Changes in job descriptions, increasing employee autonomy, and opportunities to develop a safer workplace are among the determining factors for injury and accident prevention. A positive safety climate is important to maintain a safer workplace. However, employees are the most important agents of change, when they demonstrate positive attitudes, agreeability, and acceptance of a safe workplace. 
INTERNATIONAL JOURNAL OF ACADEMIC RESEARCH ECONOMICS AND MANAGEMENT SCIENCES

Vol. 10, No. 1, 2020, E-ISSN: 2226-3624 @ 2020 HRMARS

\section{References}

Aarons, G., \& Sawitzky, A. (2006). Organizational Culture and Climate and Mental Health Provider Attitudes Toward Evidence-Based Practice. Psychological Serv, 3(1), 61-72.

Adilla, N., Hadi, A., Bahri, S., Guan, N. Y., How, V., \& Rahman, R. A. (2017). Association between Non-Reporting of Accident and Contributing Factors in Ma Malaysia's Construction Industry. In Proceedings of The 2nd Asian Conference on Ergonomics and Design (Vol. 53, pp. 648-651).

Agnew, C., Flin, R., \& Mearns, K. (2013). Patient safety climate and worker safety behaviors in acute hospitals in Scotland. Journal of Safety Research, 45, 95-101. https://doi.org/10.1016/j.jsr.2013.01.008

Ahn, S., Lee, S., \& Steel, R. P. (2013). Effects of Workers' Social Learning: Focusing on Absence Behavior. Journal of Construction Engineering and Management, 139(8), 1015-1025. https://doi.org/10.1061/(asce)co.1943-7862.0000680

Alaarj, S., Mohamed, Z. A., Salwa, U., \& Bustamam, A. (2017). The effect Knowledge Management Capabilities on Performance of Companies : A study of Service Sector. International Journal of Economic Research, 14(15).

Ali, H., Abdullah, N. A. C., \& Subramaniam, C. (2009). Management practice in safety culture and its influence on workplace injury: an industrial study in Malaysia. Disaster Prevention and Management, 18(5), 470-477.

Arnol, M. Y. (2018). The Influence of Organizational Commitment, Conflict Resolution Skills, Safety Climate for Safety Accidents On Manufacturing Industry in East Java Province ., 6(8), 35-38.

Aryee, S., Sun, L. Y., Chen, Z. X. G., \& Debrah, Y. A. (2008). Abusive supervision and contextual performance: The mediating role of emotional exhaustion and the moderating role of work unit structure. Management and Organization Review, 4(3), 393-411. https://doi.org/10.1111/j.1740-8784.2008.00118.x

Aytac, S., \& Dursun, S. (2011). The Effect on Job Satisfaction and Stress of the Perceptions of Violence Climate in the Workplace. Mediterranean Journal of Social Sciences, 2(3), 70-77. https://doi.org/10.5901/mjss.2011.v2n3p70

Baba, V. V, Tourigny, L., Wang, X., \& Liu, W. (2009). Proactive Personality and Work Performance in China: The Moderating Effects of Emotional Exhaustion and Perceived Safety Climate. Canadian Journal of Administrative Sciences (Canadian Journal of Administrative Sciences), 26(1), 23-37. Retrieved from 10.1002/CJAS.90\%5Cnhttp://search.ebscohost.com/login.aspx?direct=true\&db=buh\&AN= 38813143\&site=ehost-live

Bahari, S. F., \& Clarke, S. (2013). Cross-validation of an employee safety climate model in Malaysia. Journal of Safety Research, 45, 1-6. https://doi.org/10.1016/j.jsr.2012.12.003

Becher, H., Dollard, M. F., Smith, P., \& Li, J. (2018). Predicting circulatory diseases from psychosocial safety climate: A prospective cohort study from Australia. International Journal of Environmental Research and Public Health, 15(3), 1-12. https://doi.org/10.3390/ijerph15030415

Belschak, F. D., \& Den Hartog, D. N. (2010). Pro-Self, Prosocial, and Pro-Organizational Foci of Proactive Beahviour: Differential Antecedents and Consequences. Journal of Occupational and Organizational Psychology, 83, 475-498. https://doi.org/10.1348/096317909x439208 
Berberoglu, A. (2018). Impact of organizational climate on organizational commitment and perceived organizational performance: Empirical evidence from public hospitals. BMC Health Services Research, 18(1), 1-9. https://doi.org/10.1186/s12913-018-3149-z

Bertolino, M., Truxillo, D. M., \& Fraccaroli, F. (2011). Age as moderator of the relationship of proactive personality with training motivation , perceived career development from training , and training behavioral intentions, 263(January), 248-263. https://doi.org/10.1002/job

Beus, J. M., McCord, M. A., \& Zohar, D. (2016). Workplace safety: A review and research synthesis. Organizational Psychology Review, 6(4), 352-381. https://doi.org/10.1177/2041386615626243

Beus, J. M., Payne, S. C., Bergman, M. E., \& Arthur, W. (2010). Safety climate and injuries: an examination of theoretical and empirical relationships. The Journal of Applied Psychology, 95(4), 713-727. https://doi.org/10.1037/a0019164

Bjørkelo, B., Einarsen, S., \& Matthiesen, S. B. (2010). Predicting proactive behaviour at work: Exploring the role of personality as an antecedent of whistleblowing behaviour. Journal of Occupational and Organizational Psychology, 83(2), 371-394. https://doi.org/10.1348/096317910X486385

Blair, B. E. (2003). Culture \& Leadership. Professional Safety, (June), 18-22.

Brown, M. E., Treviño, L. K., \& Harrison, D. A. (2005). Ethical leadership: A social learning perspective for construct development and testing. Organizational Behavior and Human Decision Processes, 97(2), 117-134. https://doi.org/10.1016/j.obhdp.2005.03.002

Brown, R. ., \& Holmes, H. (1986). The use of a factor-analytic procedure for assessing the validity of an employee safety climate model. Accident Analysis \& Prevention, 18(6), 455-470. https://doi.org/10.1016/0001-4575(86)90019-9

Cabrera-Nguyen, P. (2010). Author Guidelines for Reporting Scale Development and Validation Results in the Journal of the Society for Social Work and Research. Journal of the Society for Social Work and Research, 1(2), 99-103. https://doi.org/10.5243/jsswr.2010.8

Carlson, D. S., Witt, L. A., Zivnuska, S., Kacmar, K. M., \& Grzywacz, J. G. (2008). Supervisor appraisal as the link between family-work balance and contextual performance. Journal of Business and Psychology, 23(1-2), 37-49. https://doi.org/10.1007/s10869-008-9083-z

Chakrabarty, D. (2018). Behaviour-Based Safety ( BBS ) Study of an Oil \& Gas Industry in India. International Journal of Engineering Technology Science and Research, 5(3), 936-940.

Choudhry, R. M. (2014). Behavior-based safety on construction sites: a case study. Accident; Analysis and Prevention, 70, 14-23. https://doi.org/10.1016/j.aap.2014.03.007

Clark, D. M. (1999). Anxiety disorders: Why they persist and how to treat them. Behaviour Research and Therapy, 37(SUPPL. 1), 5-27. https://doi.org/10.1016/S0005-7967(99)000480

Clarke, S. P., Sloane, D. M., \& Aiken, L. H. (2002). Effects of hospital staffing and organizational climate on needlestick injuries to nurses. American Journal of Public Health, 92(7), 11151119. https://doi.org/10.2105/AJPH.92.7.1115

Clarke, S., Probst, T. M., Guldenmund, F., Passmore, J., Clarke, S., Probst, T. M., ... Passmore, J. (2016). The psychology of occupational safety and workplace health. The Wiley Blackwell handbook of the psychology of occupational safety and workplace health.

Clayton, B. C. (2015). Shared vision and autonomous motivation vs. financial incentives driving success in corporate acquisitions. Frontiers in Psychology, 6(JAN), 1-19. 
INTERNATIONAL JOURNAL OF ACADEMIC RESEARCH ECONOMICS AND MANAGEMENT SCIENCES

Vol. 10, No. 1, 2020, E-ISSN: 2226-3624 @ 2020 HRMARS

https://doi.org/10.3389/fpsyg.2015.00466

Clissold, G., Buttigieg, D. M., \& Cieri, H. De. (2012). A psychological approach to, (June 2011), 92109. https://doi.org/10.1111/j.1744-7941.2011.00002.x

Conchie, S. M. (2013). Transformational leadership, intrinsic motivation, and trust: a moderatedmediated model of workplace safety. Journal of Occupational Health Psychology, 18(2), 198-210. https://doi.org/10.1037/a0031805

Cooper, M. D. (2009). Behavioral Safety Interventions. Professional Safety, 54(2), 36-45. https://doi.org/10.1080/07373930500538915

Cooper, M. D., \& Phillips, R. a. (2004a). Exploratory analysis of the safety climate and safety behavior relationship. Journal of Safety Research, 35(5), 497-512. https://doi.org/10.1016/j.jsr.2004.08.004

Cooper, M. D., \& Phillips, R. a. (2004b). Exploratory analysis of the safety climate and safety behavior relationship. Journal of Safety Research, 35(5), 497-512. https://doi.org/10.1016/j.jsr.2004.08.004

Coyle, I. R., Sleeman, S. D., \& Adams, N. (1995). Safety Climate. Journal of Safety Re, 26(4), 247254.

Cunningham, T., \& Jacobson, J. (2018). Safety Talk and Safety Culture: Discursive Repertoires as Indicators of Workplace Safety and Health Practice and Readiness to Change. Annals of Work Exposures and Health, 13(62), 55-64. https://doi.org/10.1093/annweh/wxy035.Safety

Curcuruto, M., Conchie, S. M., Mariani, M. G., \& Violante, F. S. (2015). The role of prosocial and proactive safety behaviors in predicting safety performance. Safety Science. https://doi.org/10.1016/j.ssci.2015.07.032

Curcuruto, Matteo, \& Griffin, M. A. (2018). Prosocial and proactive "safety citizenship behaviour" (SCB): The mediating role of affective commitment and psychological ownership. Safety Science. https://doi.org/10.1016/j.ssci.2017.12.010

Curcuruto, Matteo, Parker, S. K., \& Griffin, M. A. (2019). Proactivity towards workplace safety improvement: an investigation of its motivational drivers and organizational outcomes. European Journal of Work and Organizational Psychology, 28(2), 221-238. https://doi.org/10.1080/1359432X.2019.1572115

Dahl, Ø., Fenstad, J., \& Kongsvik, T. (2014). Antecedents of safety-compliant behaviour on offshore service vessels: a multi-factorial approach. Maritime Policy \& Management, 41(1), 20-41. https://doi.org/10.1080/03088839.2013.780311

de Jonge, J., Frewer, L., Van Trijp, H., Jan Renes, R., de Wit, W., \& Timmers, J. (2004). Monitoring consumer confidence in food safety: An exploratory study. British Food Journal, 106(June 2015), 837-849. https://doi.org/10.1108/00070700410561423

DeJoy, D. M., Schaffer, B. S., Wilson, M. G., Vandenberg, R. J., \& Butts, M. M. (2004). Creating safer workplaces: Assessing the determinants and role of safety climate. Journal of Safety Research. https://doi.org/10.1016/j.jsr.2003.09.018

Denison, D. R. (1996). What is the Difference between Organizational Culture and Organizational Climate ? A Native' s Point of View on a Decade of Paradigm Wars Author ( $s$ ): Daniel R. Denison Source: The Academy of Management Review, Vol . 21, No . 3 ( Jul ., 1996 ), pp . Academy of Management Review, 21(3), 619-654. https://doi.org/10.5465/amr.1996.9702100310

Depasquale, J., \& Geller, E. S. (1999). Critical success factors for behavior-based safety : A study 
INTERNATIONAL JOURNAL OF ACADEMIC RESEARCH ECONOMICS AND MANAGEMENT SCIENCES

Vol. 10, No. 1, 2020, E-ISSN: 2226-3624 @ 2020 HRMARS

of twenty industry-wide One-on-one interviews and focus-group meetings were held at 20 organizations that had implemented a behavior-based safety ( BBS ) process in order to find reasons for pro, 30(4), 237-249.

Dester, W., \& Blockley, D. (1995). Safety - behaviour and culture in construction. Engineering, Construction and Architectural Management, 2(1), 17-26. https://doi.org/10.1108/eb021000

Diaz-Vilela, L. F., Rodriguez, N. D., Isla-Diaz, R., Diaz-Cabrera, D., Hernández-Fernaud, E., \& Rosales-Sánchez, C. (2015). Relationships between contextual and task performance and interrater agreement: Are there any? PLOS ONE, 10(10), 1-13. https://doi.org/10.1371/journal.pone.0139898

Diaz, R. I., \& Cabrera, D. D. (1997). SAFETY CLIMATE AND ATTITUDE AS EVALUATION MEASURES OF ORGANIZATIONAL SAFETY. Accident Analysis \& Prevention, 29(5), 643-650. Retrieved from https://ac.els-cdn.com/S0001457597000158/1-s2.0-S0001457597000158main.pdf?_tid=03e1e701-44d0-4fb3-a6c6d642d8e0609f\&acdnat=1548142309_87820e67034253ea80ca509acc33569c

Díaz, R. I., \& Cabrera, D. D. (1997). Safety climate and attitude as evaluation measures of organizational safety. Accident Analysis and Prevention, 29(5), 643-650. https://doi.org/10.1016/S0001-4575(97)00015-8

Dickson, M. W., Resick, C. J., \& Hanges, P. J. (2006). When organizational climate is unambiguous, it is also strong. Journal of Applied Psychology, 91(2), 351-364. https://doi.org/10.1037/0021-9010.91.2.351

Dickson, M. W., Smith, D. B., Grojean, M. W., \& Ehrhart, M. (2001). An organizational climate regarding ethics: The outcome of leader values and the practices that reflect them. Leadership Quarterly, 12(2), 197-217. https://doi.org/10.1016/S1048-9843(01)00069-8

Didla, S., Mearns, K., \& Flin, R. (2009). Safety citizenship behaviour: a proactive approach to risk management. Journal of Risk Research, 12(3-4), 475-483. https://doi.org/10.1080/13669870903041433

Donoso, L. M. B., Demerouti, E., Garrosa Hernández, E., Moreno-Jiménez, B., \& Carmona Cobo, I. (2015). Positive benefits of caring on nurses' motivation and well-being: A diary study about the role of emotional regulation abilities at work. International Journal of Nursing Studies, 52(4), 804-816. https://doi.org/10.1016/j.ijnurstu.2015.01.002

Dormann, C., \& Zapf, D. (1999). Social support, social stressors at work, and depressive symptoms: Testing for main and moderating effects with Structural Equations in a Longitudinal Study. Journal of Applied Psychology, 84(6), 874-884.

Dorn, L., \& Brown, B. (2003). Making sense of invulnerability at work - A qualitative study of police drivers. Safety Science, 41(10), 837-859. https://doi.org/10.1016/S0925-7535(02)00036-X

Du, D., Derks, D., Bakker, A. B., \& Lu, C. Q. (2018). Does homesickness undermine the potential of job resources? A perspective behavior-home resources model. Journal of Organizational Behavior, 39(1), 96-112. https://doi.org/10.1002/job.2212

Dust, S. B., Resick, C. J., Margolis, J. A., Mawritz, M. B., \& Greenbaum, R. L. (2018). Ethical Leadership and Employee Success: Examining the Roles of Psychological Empowerment and Emotional Exhaustion. The Leadership Quarterly.

Dzewaltowski, D. A., Noble, J. M., \& Shaw, J. M. (1990). Physical Activity Participation: Social Cognitive Theory versus the Theories of Reasoned Action and Planned Behavior. Journal of 
Sport and Exercise Psychology, 12(4), 388-405. https://doi.org/10.1123/jsep.12.4.388

Eagly, A. (1992). Uneven Progress - Social-Psychology and the Study of Attitudes. Journal of Personality and Social Psychology, 63(5), 693-710.

Ersen, Ö., \& Bilgiç, R. (2018). The effect of proactive and preventive coping styles on personal and organizational outcomes: Be proactive if you want good outcomes. Cogent Psychology, 5(1), 1-14. https://doi.org/10.1080/23311908.2018.1492865

Evans, B., Glendon, A. I., \& Creed, P. A. (2007). Development and initial validation of an Aviation Safety Climate Scale. Journal of Safety Research, 38(6), 675-682. https://doi.org/10.1016/j.jsr.2007.09.005

Flin, R., Burns, C., Mearns, K., Yule, S., \& Robertson, E. M. (2006). Measuring safety climate in health care. Quality and Safety in Health Care, 15(2), 109-115. https://doi.org/10.1136/qshc.2005.014761

Folkman, W. (2018). Decision-making in Risk Management. In A. Hessami (Ed.), Perspectives on Risk, Assessment and Management Paradigms. London.

Ghahramani, A., \& Khalkhali, H. R. (2015). Development and Validation of a Safety Climate Scale for Manufacturing Industry. Safety and Health at Work, 6(2), 97-103. https://doi.org/10.1016/j.shaw.2015.01.003

Glendon, A. ., \& Litherland, D. K. (2001). Safety climate factors, group differences and safety behaviour in road construction. Safety Science, 39, 157-188. https://doi.org/10.1016/S0925-7535(01)00006-6

Glendon, A. I., \& Stanton, N. A. (2000). Perspectives on safety culture. Safety Science, 34(1-3), 193-214. https://doi.org/10.1016/S0925-7535(00)00013-8

Glisson, C., \& Hemmelgarn, A. (1998). The effects of organizational climate and interorganizational coordination on the quality and outcomes of children's service systems. Child Abuse and Neglect, 22(5), 401-421. https://doi.org/10.1016/S0145-2134(98)00005-2

Golkar, A., Castro, V., \& Olsson, A. (2015). Social learning of fear and safety is determined by the demonstrator's racial group. Biology Letters, 11(1). https://doi.org/10.1098/rsbl.2014.0817

Gonçalves, S. M. P., da Silva, S. A., Lima, M. L., \& Meliá, J. L. (2008). The impact of work accidents experience on causal attributions and worker behaviour. Safety Science, 46(6), 992-1001. https://doi.org/10.1016/j.ssci.2007.11.002

Graen, G. B., \& Uhl-Bien, M. (1995). Relationship-based approach to leadership: Development of leader-member exchange (LMX) theory of leadership over 25 years: Applying a multi-level multi-domain perspective. The Leadership Quarterly, 6(2), 219-247. https://doi.org/10.1016/1048-9843(95)90036-5

Grant, A. M. (2013). Rocking the Boat But Keeping It Steady: the Role of Emotion Regulation. Academy of Management Journal, 56(6), 1703-1723. https://doi.org/10.5465/amj.2011.0035

Greenglass, E. R., \& Fiksenbaum, L. (2009). Proactive Coping, Positive Affect, and Well-Being. European Psychologist, 14(1), 29-39. https://doi.org/10.1027/1016-9040.14.1.29

Greenslade, J. H., \& Jimmieson, N. L. (2007). Distinguishing between task and contextual performance for nurses: Development of a job performance scale. Journal of Advanced Nursing, 58(6), 602-611. https://doi.org/10.1111/j.1365-2648.2007.04256.x

Griffin, M. a., \& Hu, X. (2013). How leaders differentially motivate safety compliance and safety participation: The role of monitoring, inspiring, and learning. Safety Science, 60, 196-202. 
INTERNATIONAL JOURNAL OF ACADEMIC RESEARCH ECONOMICS AND MANAGEMENT SCIENCES

Vol. 10, No. 1, 2020, E-ISSN: 2226-3624 @ 2020 HRMARS

https://doi.org/10.1016/j.ssci.2013.07.019

Griffin, M. a., \& Neal, A. (2000). Perceptions of safety at work: A framework for linking safety climate to safety performance, knowledge, and motivation. Journal of Occupational Health Psychology, 5(3), 347-358. https://doi.org/10.1037//1076-8998.5.3.347

Griffin, M. a, Hodkiewicz, M. R., Dunster, J., Kanse, L., Parkes, K. R., Finnerty, D., ... Unsworth, K. L. (2014). A conceptual framework and practical guide for assessing fitness-to-operate in the offshore oil and gas industry. Accident; Analysis and Prevention, 68, 156-171. https://doi.org/10.1016/j.aap.2013.12.005

Grill, M., Nielsen, K. J., Grill, M., Nielsen, K., Grytnes, R., \& Pousette, A. (2018). The leadership practices of construction site managers and their influence on occupational safety : an observational study of transformational and passive / avoidant leadership The leadership practices of construction site managers and their influence on . Construction Management and Economics, O(0), 1-16. https://doi.org/10.1080/01446193.2018.1526388

Grill, M., Pousette, A., Nielsen, K., Grytnes, R., \& Törner, M. (2017). Supervisors and teachers' influence on expectations on empowering leadership among students in vocational education and training. Empirical Research in Vocational Education and Training. https://doi.org/10.1186/s40461-017-0046-3

Haas, E. J., Eiter, B., Hoebbel, C., \& Ryan, M. E. (2019). The Impact of Job, Site, and Industry Experience on Worker Health and Safety. Safety, 5(1), 16. https://doi.org/10.3390/safety5010016

Hall, G. B., Dollard, M. F., \& Coward, J. (2010). Psychosocial safety climate: Development of the PSC-12. International Journal of Stress Management, 17(4), 353-383. https://doi.org/10.1037/a0021320

Hellriegel, D. O. N., \& Slocum, J. W. (1973a). Hellriegel,1973-org.climate-measures, research n contigency. https://doi.org/10.2307/254979

Hellriegel, D. O. N., \& Slocum, J. W. (1973b). Organizational Climate: Measures, research and contigencies. The Academy of Management Journal, 17(255-280). https://doi.org/10.2307/254979

Heyer, N. J., Franklin, G., Rivara, F. P., Parker, P., \& Haug, J. a. (1992). Occupational injuries among minors doing farm work in Washington State: 1986 to 1989. American Journal of Public Health, 82(4), 557-560. Retrieved from http://www.pubmedcentral.nih.gov/articlerender.fcgi?artid=1694090\&tool=pmcentrez\&r endertype $=$ abstract

Ho, V. T., \& Astakhova, M. N. (2018). Disentangling passion and engagement: An examination of how and when passionate employees become engaged ones. Human Relations, 71(7), 9731000. https://doi.org/10.1177/0018726717731505

Hoe, V. (2014). 0254 Commuting Accident in Malaysia: Are we doing enough? Occupational and Environmental Medicine, 71 Suppl 1(Suppl 1), A94. https://doi.org/10.1136/oemed-2014102362.294

Hofmann, D. A., Morgeson, F. P., \& Gerras, S. J. (2003). Climate as a moderator of the relationship between leader-member exchange and content specific citizenship: Safety climate as an exemplar. Journal of Applied Psychology, 88(1), 170-178. https://doi.org/10.1037/00219010.88.1.170

Hoonakker, P., Loushine, T., Carayon, P., Kallman, J., Kapp, A., \& Smith, M. J. (2005). The effect of 
safety initiatives on safety performance: A longitudinal study. Applied Ergonomics, 36(4 SPEC. ISS.), 461-469. https://doi.org/10.1016/j.apergo.2004.07.006

Howardson, G. N., Karim, M. N., \& Horn, R. G. (2017). The Latent Change Score Model: A More Flexible Approach to Modeling Time in Self-Regulated Learning. Journal of Business and Psychology, 32(3), 317-334. https://doi.org/10.1007/s10869-016-9475-4

Hoy, W. (1990). Organizational Climate and Culture: A Conceptual Analysis of the School Workplace - Journal of Educational and Psychological Consultation. Journal of Educational and Psychological Consultation, 1(2), 149-168. https://doi.org/10.1207/s1532768xjepc0102_4

Hu, X., Griffin, M., Yeo, G., Kanse, L., Hodkiewicz, M., \& Parkes, K. (2018). A new look at compliance with work procedures: An engagement perspective. Safety Science. https://doi.org/10.1016/j.ssci.2018.01.019

Huang, Y. H., Lee, J., McFadden, A. C., Murphy, L. A., Robertson, M. M., Cheung, J. H., \& Zohar, D. (2016). Beyond safety outcomes: An investigation of the impact of safety climate on job satisfaction, employee engagement and turnover using social exchange theory as the theoretical framework. Applied Ergonomics, 55, 248-257. https://doi.org/10.1016/j.apergo.2015.10.007

Huang, Y. H., Zohar, D., Robertson, M. M., Garabet, A., Lee, J., \& Murphy, L. a. (2013). Development and validation of safety climate scales for lone workers using truck drivers as exemplar. Transportation Research Part F: Traffic Psychology and Behaviour, 17, 5-19. https://doi.org/10.1016/j.trf.2012.08.011

Hutchinson, A., Cooper, K. L., Dean, J. E., Mclntosh, A., Patterson, M., Stride, C. B., ... Smith, C. M. (2006). Use of a safety climate questionnaire in UK health care: Factor structure, reliability and usability. Quality and Safety in Health Care, 15(5), 347-353. https://doi.org/10.1136/qshc.2005.016584

Hystad, S. W., \& Bye, H. H. (2013). Safety behaviours at sea: The role of personal values and personality hardiness. Safety Science, 57, 19-26. https://doi.org/10.1016/j.ssci.2013.01.018

Idris, M. A., Dollard, M. F., Coward, J., \& Dormann, C. (2012). Psychosocial safety climate: Conceptual distinctiveness and effect on job demands and worker psychological health. Safety Science, 50(1), 19-28. https://doi.org/10.1016/j.ssci.2011.06.005

Idris, M. A., Dollard, M. F., \& Yulita. (2014). Psychosocial safety climate, emotional demands, burnout, and depression: a longitudinal multilevel study in the Malaysian private sector. Journal of Occupational Health Psychology, 19(3), 291-302. https://doi.org/10.1037/a0036599

Ismail, F. (2014). Steps for the Behavioural Based Safety: A Case Study Approach. International Journal of Engineering and Technology, 4(5), 594-596. https://doi.org/10.7763/ijet.2012.v4.440

Javaid, M. U., Shahrul, A., Isha, N., Sabir, A. A., Ghazali, Z., \& Nübling, M. (2018). Does Psychosocial Work Environment Factors Predict Stress and Mean Arterial Pressure in the Malaysian Industry Workers? Biomed Research International. https://doi.org/10.1155/2018/9563714

Jiang, L., Lavaysse, L. M., \& Probst, T. M. (2018). Safety climate and safety outcomes: A metaanalytic comparison of universal vs. industry-specific safety climate predictive validity. Work and Stress, O(0), 1-17. https://doi.org/10.1080/02678373.2018.1457737

Johnson, S. E. (2007). The predictive validity of safety climate. Journal of Safety Research, 38(5), 
INTERNATIONAL JOURNAL OF ACADEMIC RESEARCH ECONOMICS AND MANAGEMENT SCIENCES

Vol. 10, No. 1, 2020, E-ISSN: 2226-3624 @ 2020 HRMARS

511-521. https://doi.org/10.1016/j.jsr.2007.07.001

Jones, S. G., Momin, S. R., Good, M. W., Shea, T. K., \& Patric, K. (2009). Distal upper and lower limb fractures associated with thiazolidinedione use. American Journal of Managed Care, 15(8), 491-496. https://doi.org/10.1177/0193945916659507

Joyce, W. F., Slocum, J. W., Slocum, J., \& Joyce, W. F. (1982). Correlates of climate discrepancy, $1-35$.

Judge, T. A., LePine, J. A., \& Rich, B. L. (2006). Loving yourself abundantly: Relationship of the narcissistic personality to self- and other perceptions of workplace deviance, leadership, and task and contextual performance. Journal of Applied Psychology, 91(4), 762-776. https://doi.org/10.1037/0021-9010.91.4.762

Katz-Navon, T., Naveh, E., \& Stern, Z. (2007). Safety self-efficacy and safety performance. International Journal of Health Care Quality Assurance, 20(7), 572-584. https://doi.org/10.1108/09526860710822716

Kaya, S., Barsbay, S., \& Karabulut, E. (2010). The Turkish version of the safety attitudes questionnaire: Psychometric properties and baseline data. Quality and Safety in Health Care, 19(6), 572-577. https://doi.org/10.1136/qshc.2008.032003

Kines, P., Andersen, L. P. S., Spangenberg, S., Mikkelsen, K. L., Dyreborg, J., \& Zohar, D. (2010). Improving construction site safety through leader-based verbal safety communication. Journal of Safety Research, 41(5), 399-406. https://doi.org/10.1016/j.jsr.2010.06.005

Kines, P., Lappalainen, J., Mikkelsen, K. L., Olsen, E., Pousette, A., Tharaldsen, J., ... Törner, M. (2011). Nordic Safety Climate Questionnaire (NOSACQ-50): A new tool for diagnosing occupational safety climate. International Journal of Industrial Ergonomics, 41(6), 634-646. https://doi.org/10.1016/j.ergon.2011.08.004

Kinman, G., \& Jones, F. (2005). Lay representations of workplace stress: What do people really mean when they say they are stressed? Work \& Stress, 19(2), 101-120. https://doi.org/10.1080/02678370500144831

Koene, B. A. S., Vogelaar, A. L. W., \& Soeters, J. L. (2002). Leadership effects on organizational climate and financial performance: Local leadership effect in chain organizations. Leadership Quarterly, 13(3), 193-215. https://doi.org/10.1016/S1048-9843(02)00103-0

Kolarcik, P., Geckova, A. M., Orosova, O., van Dijk, J. P., \& Reijneveld, S. A. (2009). To what extent does socioeconomic status explain differences in health between Roma and non-Roma adolescents in Slovakia? Social Science and Medicine, 68(7), 1279-1284. https://doi.org/10.1016/j.socscimed.2008.12.044

Lahuis, D. M., Martin, N. R., \& Avis, J. M. (2005). Investigating Nonlinear Performance Relations for Clerical Employees. Human Performance, 18(3), 309-329. https://doi.org/10.1207/s15327043hup1803

Law, R., Dollard, M. F., Tuckey, M. R., \& Dormann, C. (2011). Psychosocial safety climate as a lead indicator of workplace bullying and harassment, job resources, psychological health and employee engagement. Accident; Analysis and Prevention, 43(5), 1782-1793. https://doi.org/10.1016/j.aap.2011.04.010

Lewin, K. (1943). Defining the "field at a given time." Psychological Review, 50(3), 292-310.

Liu, H., Burns, R. M., Schaefer, A. G., Ruder, T., Nelson, C., Haviland, A. M., ... Mendeloff, J. (2010). The Pennsylvania certified safety committee program: an evaluation of participation and effects on work injury rates. American Journal of Industrial Medicine, 53(8), 780-791. 
INTERNATIONAL JOURNAL OF ACADEMIC RESEARCH ECONOMICS AND MANAGEMENT SCIENCES

Vol. 10, No. 1, 2020, E-ISSN: 2226-3624 @ 2020 HRMARS

https://doi.org/10.1002/ajim.20861

Liu, Y., Zhao, S., Jiang, L., \& Li, R. (2015). When Does a Proactive Personality Enhance an Employee's Whistle-Blowing Intention?: A Cross-Level Investigation of the Employees in Chinese Companies. Ethics \& Behavior, 8422(July 2016), 1-18. https://doi.org/10.1080/10508422.2015.1113382

Locke, E. A., Frederick, E., Lee, C., \& Bobko, P. (1984). Effect of self-efficacy, goals, and task strategies on task performance. Journal of Applied Psychology, 69(2), 241-251. https://doi.org/10.1037/0021-9010.69.2.241

Locke, E. A., \& Latham, G. P. (1990). A theory of goal setting \& task performance. Prentice-Hall, Inc.

Low, B., Man, S., \& Chan, A. (2018). The Risk-Taking Propensity of Construction Workers-An Application of Quasi-Expert Interview. International Journal of Environmental Research and Public Health, 15(10), 2250. https://doi.org/10.3390/ijerph15102250

Mackinnon, S. P., \& Sherry, S. B. (2012). Perfectionistic self-presentation mediates the relationship between perfectionistic concerns and subjective well-being: A three-wave longitudinal study. Personality and Individual Differences, 53(1), 22-28. https://doi.org/10.1016/j.paid.2012.02.010

McCoy, D. C., Roy, A. L., \& Sirkman, G. M. (2013). Neighborhood Crime and School Climate as Predictors of Elementary School Academic Quality: A Cross-Lagged Panel Analysis. American Journal of Community Psychology, 52(1-2), 128-140. https://doi.org/10.1007/s10464-0139583-5

McFadden, K. L., Henagan, S. C., \& Gowen III, C. R. (2009). The patient safety chain: Transformational leadership's effect on patient safety culture, initiatives, and outcomes. Journal of Operation Management, 27(3), 390-404. https://doi.org/10.1016/j.jom.2009.01.001

McSween, T., \& Moran, D. J. (2017). Assessing and Preventing Serious Incidents with Behavioral Science: Enhancing Heinrich's Triangle for the 21st Century. Journal of Organizational Behavior Management, 37(3-4), 283-300. https://doi.org/10.1080/01608061.2017.1340923

Mearns, K., Whitaker, S. M., \& Flin, R. (2001). Benchmarking safety climate in hazardous environments: A longitudinal, interorganizational approach. Risk Analysis, 21(4), 771-786. https://doi.org/10.1111/0272-4332.214149

Meliá, J. L., Mearns, K., Silva, S. A., \& Lima, M. L. (2008). Safety climate responses and the perceived risk of accidents in the construction industry. Safety Science, 46(6), 949-958.

Mersman, J. L., \& Donaldson, S. I. (2000). Factors Affecting the Convergence of Self-Peer Ratings on Contextual and Task Performance. Human Performance, 13(3), 299-322. https://doi.org/10.1207/S15327043HUP1303_4

Michael, J. H., Evans, D. D., Jansen, K. J., \& Haight, J. M. (2005). Management commitment to safety as organizational support: Relationships with non-safety outcomes in wood manufacturing employees. Journal of Safety Research, 36(2), 171-179. https://doi.org/10.1016/j.jsr.2005.03.002

Mohammed, S., Mathieu, J. E., Bartlett, A. L. B., \& Wiley, J. (2011). Task Performance, Leadership Task Performance, and Contextual Performance: Considering the Influence of Team- and Task-Related Composition Variablest, 23(7), 795-814. https://doi.org/10.1002/job. 
Montes, F. J. L., Moreno, A. R., \& Fernández, L. M. M. (2004). Assessing the organizational climate and contractual relationship for perceptions of support for innovation. International Journal of Manpower, 25(2). https://doi.org/10.1108/01437720410535972

Morgan, H., \& Raffle, C. (1999). Response to 'Does Reducing Safety Behaviours Improve Treatment Response in Patients with Social Phobia?' Australian \& New Zealand Journal of Psychiatry, 34(5), 871-872. https://doi.org/10.1080/j.1440-1614.2000.0822c.x

Morrow, S. L., McGonagle, A. K., Dove-Steinkamp, M. L., Walker, C. T., Marmet, M., \& BarnesFarrell, J. L. (2010). Relationships between psychological safety climate facets and safety behavior in the rail industry: a dominance analysis. Accident; Analysis and Prevention, 42(5), 1460-1467. https://doi.org/10.1016/j.aap.2009.08.011

Motowildo, S., Borman, W., \& Schmit, M. (1997). A Theory of individual differences in contextual and task performance_Motowidlow, Borman, Schmit_1997.pdf. Human Performance, 10(2), 71-83.

Nahrgang, J. D., Morgeson, F. P., \& Hofmann, D. a. (2011). Safety at work: a meta-analytic investigation of the link between job demands, job resources, burnout, engagement, and safety outcomes. The Journal of Applied Psychology, 96(1), 71-94. https://doi.org/10.1037/a0021484

Neal, A, Gri, M. A., \& Hart, P. M. (2000). The impact of organizational climate on safety climate and individual behavior. Safety Science, 34, 99-109.

Neal, Andrew, \& Griffin, M. A. (2002). Safety Climate and Safety Behaviour. Australian Journal of Management, 27(1_suppl), 67-75. https://doi.org/10.1177/031289620202701S08

Neal, Andrew, \& Griffin, M. A. (2006). A study of the lagged relationships among safety climate, safety motivation, safety behavior, and accidents at the individual and group levels. Journal of Applied Psychology, 91(4), 946-953. https://doi.org/10.1037/0021-9010.91.4.946

Nel, W. S., \& Visitor, B. A. W. (1998). in the Mining Industry, (June), 110-115. https://doi.org/10.1063/1.1943413

Neto, M. T. R., Silva, L. C. F. da, \& Ferreira, C. A. A. (2018). Influence of Internal Communication on t he Organizations' Performance: Proposition of Model. FUTURE STUDIES RESEARCH JOURNAL -, 10(2), 214-237.

Newaz, M. T., Davis, P., Jefferies, M., \& Pillay, M. (2019). The psychological contract: A missing link between safety climate and safety behaviour on construction sites. Safety Science, 112(March 2018), 9-17. https://doi.org/10.1016/j.ssci.2018.10.002

Niskanen, T. (1994). Safety climate in the road administration. Safety Science, 17(4), 237-255. https://doi.org/10.1016/0925-7535(94)90026-4

Nordfjærn, T., Jrgensen, S., \& Rundmo, T. (2011). A cross-cultural comparison of road traffic risk perceptions, attitudes towards traffic safety and driver behaviour. Journal of Risk Research, 14(6), 657-684. https://doi.org/10.1080/13669877.2010.547259

O'Connell, M. S., Hartman, N. S., McDaniel, M. A., Grubb, W. L., \& Lawrence, A. (2007). Incremental validity of situational judgment tests for task and contextual job performance. International Journal of Selection and Assessment, 15(1), 19-29. https://doi.org/10.1111/j.1468-2389.2007.00364.x

Oah, S., Na, R., \& Moon, K. (2018). The Influence of Safety Climate, Safety Leadership, Workload, and Accident Experiences on Risk Perception: A Study of Korean Manufacturing Workers. Safety and Health at Work, 9(4), 427-433. https://doi.org/10.1016/j.shaw.2018.01.008 
INTERNATIONAL JOURNAL OF ACADEMIC RESEARCH ECONOMICS AND MANAGEMENT SCIENCES

Vol. 10, No. 1, 2020, E-ISSN: 2226-3624 @ 2020 HRMARS

Odoardi, C. (2015). The relationship between proactive goal generation and innovative behaviour at work. Journal of Management Development, 34(5), 553-565. https://doi.org/10.1108/JMD-04-2014-0037

Organ, D. W. (1997). Organizational citizenship behavior: It's construct clean-up time. Human Performance. https://doi.org/10.1207/s15327043hup1002_2

Panatik, S. A., Rajab, A., Shaari, R., Shah, I. M., Rahman, H. A., \& Badri, S. K. Z. (2012). Impact of Work-related Stress on Well-being among Academician in Malaysian Research University. 2012 International Conference on Education and Management Innovation, 30(September 2016), 37-41.

Parizad, N., Hassankhani, H., Rahmani, A., Mohammadi, E., Lopez, V., \& Cleary, M. (2018). Nurses' experiences of unprofessional behaviors in the emergency department: A qualitative study. Nursing and Health Sciences, 20(1), 54-59. https://doi.org/10.1111/nhs.12386

Patterson, M. G., West, M. A., Shackleton, V. I. V. J., Dawson, J. F., Lawthom, R., Maitlis, S., ... Wallace, A. M. (2005). Validating the organizational climate measure, 408(December 2003), 379-408.

Patterson, M., Warr, P., \& West, M. (2004). Organizational climate and company productivity: The role of employee affect and employee level. Journal of Occupational and Organizational Psychology, 77(2), 193-216. https://doi.org/10.1348/096317904774202144

Penner, L. A. (2002). Dispositional and Organizational Influences on Sustained Volunteerism: An Interactionist Perspective. Journal of Social Issues, 58(3), 447-467. https://doi.org/10.1111/1540-4560.00270

Petrou, P., Demerouti, E., Peeters, M. C. W., Schaufeli, W. B., \& Hetland, J. (2012). Crafting a job on a daily basis : Contextual correlates and the link to work engagement Conceptualizing Job Crafting as a Daily Behavior Job Crafting : Conceptualization and Dimensionality. Journal of Organizational Behavior, (January). https://doi.org/10.1002/job

Pousette, A., Larsson, S., \& Törner, M. (2008). Safety climate cross-validation, strength and prediction of safety behaviour. Safety Science, 46(3), 398-404. https://doi.org/10.1016/j.ssci.2007.06.016

Probst, T. M. (2004). Safety and Insecurity: Exploring the Moderating Effect of Organizational Safety Climate. Journal of Occupational Health Psychology, 9(1), 3-10. https://doi.org/10.1037/1076-8998.9.1.3

Purwanto, E. (2018). Moderation effects of power distance on the relationship between job characteristics, leadership empowerment, employee participation and job satisfaction: A conceptual framework. Academy of Strategic Management Journal, 17(1), 1-10.

Qualls, W. J., \& Puto, C. P. (1989). Organizational Climate and Decision Framing: An Integrated Approach to Analyzing Industrial Buying Decisions. Journal of Marketing Research, 26(2), 179. https://doi.org/10.2307/3172604

Radomsky, A. (2008). The judicious use of safety behaviour in the treatment of anxiety disorders, $1-26$.

Råheim, M., Magnussen, L. H., Sekse, R. J. T., Lunde, Å., Jacobsen, T., \& Blystad, A. (2016). Researcher-researched relationship in qualitative research: Shifts in positions and researcher vulnerability. International Journal of Qualitative Studies on Health and WellBeing, 11, 1-12. https://doi.org/10.3402/qhw.v11.30996

Reason, J. (2016). Managing the risks of organizational accidents. London: Routledge. 
Rogg, K. L., Schmidt, D. B., Shull, C., \& Schmitt, N. (2001). Human resource practices, organizational climate, and customer satisfaction. Journal of Management, 27(4), 431-449. https://doi.org/10.1016/S0149-2063(01)00102-7

Rolfe, G. (2006). Validity, trustworthiness and rigour: Quality and the idea of qualitative research. Journal of Advanced Nursing, 53(3), 304-310. https://doi.org/10.1111/j.13652648.2006.03727.x

Rotundo, M., \& Sackett, P. R. (2005). The relative importance of task, citizenship, and counterproductive performance to global ratings of job performance: A policy-capturing approach. Journal of Applied Psychology, 87(1), 66-80. https://doi.org/10.1037/00219010.87.1.66

Salkovskis, P., Clark, D., Hackman, A., Wells, A., \& Gelder, M. (1999). An experimental investigation of the role of safety-seeking behaviours in the maintenance of panic disorder with agoraphobia. Behaviour Research and Therapy, 37(6), 559-574. Retrieved from http://onlinelibrary.wiley.com/o/cochrane/clcentral/articles/035/CN00595035/frame.html

Salkovskis, P. M. (1991). The importance of behaviour in the maintenance of anxiety and panic: A cognitive account. Behavioural and Cognitive Psychotherapy, 19(1), 6-19.

Schmitt, A., Den Hartog, D. N., \& Belschak, F. D. (2016). Transformational leadership and proactive work behaviour: A moderated mediation model including work engagement and job strain. Journal of Occupational and Organizational Psychology, n/a-n/a. https://doi.org/10.1111/joop.12143

Schneider, B. (1982). Interactional Psychology and Organizational Behavior. Research Report Series, 5, 1-31.

Schneider, B. (1987). The People Make the Place. Personnel Psychology, 40(3), 437-453. https://doi.org/10.1111/j.1744-6570.1987.tb00609.x

Schneider, B., Ehrhart, M. G., \& Macey, W. (2013). Organizational Climate and Culture. Ssrn, (January 2019), 1-26. https://doi.org/10.1146/annurev-psych-113011-143809

Schneider, S. (1989). Strategy formulation: The impact of national culture. Organization Studies, 10(2), 149-168. Retrieved from http://search.ebscohost.com/login.aspx?direct=true\%7B\&\%7Ddb=bth\%7B\&\%7DAN=5953 090\%7B\&\%7Dsite=ehost-live\%7B\&\%7Dscope=site

Scott, G. (2001). Cambridge Center - 1 How to Get More People Involved in Behavior-Based Safety: Selling an Effective Process. Cambridge Center -1, 1-21.

Seo, D. C., Torabi, M. R., Blair, E. H., \& Ellis, N. T. (2004). A cross-validation of safety climate scale using confirmatory factor analytic approach. Journal of Safety Research, 35(4), 427-445. https://doi.org/10.1016/j.jsr.2004.04.006

Seppälä, T., Hankonen, N., Korkiakangas, E., Ruusuvuori, J., \& Laitinen, J. (2017). National policies for the promotion of physical activity and healthy nutrition in the workplace context: $A$ behaviour change wheel guided content analysis of policy papers in Finland. BMC Public Health, 18(1), 1-9. https://doi.org/10.1186/s12889-017-4574-3

Shamsuddin, K., Ani, M., Ismail, A., \& Ibrahim, M. (2015). Investigation the Safety, Health and Environment (SHE) Protection in Construction Area. International Research Journal of Engineering and Technology (IRJET), 2(6), 624-636. Retrieved from http://www.irjet.net/archives/V2/i6/IRJET-V2I6101.pdf 
Silva, S., Lima, M. L., \& Baptista, C. (2004). OSCl: An organisational and safety climate inventory. Safety Science, 42(3), 205-220. https://doi.org/10.1016/S0925-7535(03)00043-2

Singer, S., Lin, S., Falwell, A., Gaba, D., \& Baker, L. (2009). Relationship of safety climate and safety performance in hospitals. Health Services Research, 44(2P1), 399-421. https://doi.org/10.1111/j.1475-6773.2008.00918.x

Singer, S., Meterko, M., Baker, L., Gaba, D., Falwell, A., \& Rosen, A. (2007). Workforce perceptions of hospital safety culture: Development and validation of the patient safety climate in healthcare organizations survey. Health Services Research, 42(5), 1999-2021. https://doi.org/10.1111/j.1475-6773.2007.00706.x

Singh, V., \& Verma, A. (2018). A review, simple meta-analysis and future directions of safety climate research in manufacturing organizations. International Journal of Occupational Safety and Ergonomics, O(0), 1-27. https://doi.org/10.1080/10803548.2018.1476203

Skowron-Grabowska, B., \& Sobociński, M. D. (2018). Behaviour Based Safety (Bbs) - Advantages and Criticism. Production Engineering Archives, 20(November), 12-15. https://doi.org/10.30657/pea.2018.20.03

Spigener, J., Amato, F., \& Craig, B. N. (2002). Effective Application of Behavioral Based Processes in Offshore Operations.

Spitzmuller, M., Sin, H. P., Howe, M., \& Fatimah, S. (2015). Investigating the Uniqueness and Usefulness of Proactive Personality in Organizational Research: A Meta-Analytic Review. Human Performance, 28(4), 351-379. https://doi.org/10.1080/08959285.2015.1021041

Tholén, S. L., Pousette, A., \& Törner, M. (2013). Causal relations between psychosocial conditions, safety climate and safety behaviour - A multi-level investigation. Safety Science, 55, 62-69. https://doi.org/10.1016/j.ssci.2012.12.013

Toppazzini, M. A., \& Wiener, K. K. K. (2017). Making workplaces safer: The influence of organisational climate and individual differences on safety behaviour. Heliyon, 3(6), e00334. https://doi.org/10.1016/j.heliyon.2017.e00334

Toulson, P., \& Smith, M. (1994). The Relationship between Organizational Climate and Employee Perceptions of Personnel Management Practices. Public Personnel Management, 23(3), 453-468. https://doi.org/10.1177/009102609402300309

Trifiletti, L. B., Gielen, A. C., Sleet, D. A., \& Hopkins, K. (2005). Behavioral and social sciences theories and models: Are they used in unintentional injury prevention research? Health Education Research, 20(3), 298-307. https://doi.org/10.1093/her/cyg126

Triplett, S. M., \& Loh, J. M. I. (2018). The moderating role of trust in the relationship between work locus of control and psychological safety in organisational work teams. Australian Journal of Psychology, 70(1), 76-84. https://doi.org/10.1111/ajpy.12168

Tucker, S., \& Turner, N. (2014). Safety voice among young workers facing dangerous work: A policy-capturing approach. Safety Science, 62, 530-537.

Tuckey, M. R., Dollard, M. F., Saebel, J., \& Berry, N. M. (2010). Negative workplace behaviour: temporal associations with cardiovascular outcomes and psychological health problems in Australian police. Stress and Health, 26(5), 372-381. https://doi.org/10.1002/smi.1306

Tutar, H., Altinoz, M., \& Cakiroglu, D. (2011). The effects of employee empowerment on achievement motivation and the contextual performance of employees. African Journal of Business Management, 5(15), 6318-6329. https://doi.org/10.5897/AJBM11.085

Tyagi, P. K. (1982). Perceived Organizational Climate and the Process of Salesperson Motivation. 
Journal of Marketing Research, 19(2), 240. https://doi.org/10.2307/3151624

Uehli, K., Mehta, A. J., Miedinger, D., Hug, K., Schindler, C., Holsboer-Trachsler, E., ... Künzli, N. (2014). Sleep problems and work injuries: a systematic review and meta-analysis. Sleep Medicine Reviews, 18(1), 61-73. https://doi.org/10.1016/j.smrv.2013.01.004

Van Scotter, J. R., \& Motowidlo, S. J. (1996). Interpersonal facilitation and job dedication as separate facets of contextual performance. Journal of Applied Psychology, 81(5), 525-531. https://doi.org/10.1037/0021-9010.81.5.525

Van Scotter, J. R., Motowidlo, S. J., \& Cross, T. C. (2000). Effects of task performance and contextual performance on systemic rewards. Journal of Applied Psychology, 85(4), 526535. https://doi.org/10.1037/0021-9010.85.4.526

Vansteenwegen, D., Hermans, D., Vervliet, B., Francken, G., Beckers, T., Baeyens, F., \& Eelen, P. (2005). Return of fear in a human differential conditioning paradigm caused by a return to the original acquistion context. Behaviour Research and Therapy, 43(3), 323-336. https://doi.org/10.1016/j.brat.2004.01.001

Verbeke, W., Volgering, M., \& Hessels, M. (2002). Exploring the conceptual expansion within the field of organizational behavior: Organizational climate and organizational culture. Journal of Management Studies, (1985), 1-57.

Vinodkumar, M. N., \& Bhasi, M. (2010). Safety management practices and safety behaviour: assessing the mediating role of safety knowledge and motivation. Accident; Analysis and Prevention, 42(6), 2082-2093. https://doi.org/10.1016/j.aap.2010.06.021

Wang, M., Sun, J., Du, H., \& Wang, C. (2018). Relations between Safety Climate, Awareness, and Behavior in the Chinese Construction Industry: A Hierarchical Linear Investigation. Advances in Civil Engineering, 2018. https://doi.org/10.1155/2018/6580375

Warmerdam, A., Newnam, S., Wang, Y., Sheppard, D., Griffin, M., \& Stevenson, M. (2018). High performance workplace systems' influence on safety attitudes and occupational driver behaviour. Safety Science, 106(September 2017), 146-153. https://doi.org/10.1016/j.ssci.2018.03.016

Warr, P. (1990). The measurement of well???being and other aspects of mental health. Journal of Occupational Psychology, 63(3), 193-210. https://doi.org/10.1111/j.20448325.1990.tb00521.x

Watts, B. V., Percarpio, K., West, P., \& Mills, P. D. (2010). Use of the safety attitudes questionnaire as a measure in patient safety improvement. Journal of Patient Safety, 6(4), 206-209. https://doi.org/10.1097/PTS.0b013e3181fbbe86

Welbourne, T. M., Johnson, D. E., \& Erez, A. (1997). The Role-Based Performance Scale: Validity Analysis of a Theory-Based Measure. CAHRS Working Paper Series. Ithaca, New York. Retrieved from http://digitalcommons.ilr.cornell.edu/cahrswp

Yang, L.-Q., Spector, P. E., Chang, C.-H. D., Gallant-Roman, M., \& Powell, J. (2012). Psychosocial precursors and physical consequences of workplace violence towards nurses: a longitudinal examination with naturally occurring groups in hospital settings. International Journal of Nursing Studies, 49(9), 1091-1102. https://doi.org/10.1016/j.ijnurstu.2012.03.006

Yin, K., Xing, L., Li, C., \& Guo, Y. (2017). Are empowered employees more proactive? The contingency of how they evaluate their leader. Frontiers in Psychology, 8(NOV), 1-11. https://doi.org/10.3389/fpsyg.2017.01802

Yu, T., de Ruyter, K., Patterson, P., \& Chen, C. F. (2018). The formation of a cross-selling initiative 
climate and its interplay with service climate. European Journal of Marketing, 52(7-8), 1457-1484. https://doi.org/10.1108/EJM-08-2016-0487

Zapf, D., Dormann, C., \& Frese, M. (1996). Longitudinal studies in organizational stress research: a review of the literature with reference to methodological issues. Journal of Occupational Health Psychology, 1(2), 145-169. https://doi.org/10.1037/1076-8998.1.2.145

Zhang, J., \& Wu, C. (2014). The influence of dispositional mindfulness on safety behaviors: a dual process perspective. Accident; Analysis and Prevention, 70, 24-32. https://doi.org/10.1016/j.aap.2014.03.006

Zhang, L., Chen, H., Li, H., Wu, X., \& Skibniewski, M. J. (2018). Perceiving interactions and dynamics of safety leadership in construction projects. Safety Science, 106(May 2017), 6678. https://doi.org/10.1016/j.ssci.2018.03.007

Zhao, X., \& Peterson, E. (2017). Effects of Temporal Framing on Response to Antismoking Messages: The Mediating Role of Perceived Relevance. Journal of Health Communication. https://doi.org/10.1080/10810730.2016.1250844

Zohar, D. (1980a). Safety climate in industrial organizations: theoretical and applied implications. The Journal of Applied Psychology, 65(1), 96-102. https://doi.org/10.1037/00219010.65.1.96

Zohar, D. (1980b). Safety Climate in Industrial Organizations: Theoretical and Applied Implications. Journal of Applied Psychology, 65(1), 96-102.

Zohar, D. (2002). The effects of leadership dimensions, safety climate, and assigned priorities on minor injuries in work groups. Journal of Organisational Behaviour. Journal of Organizational Behavior, 23(1)(June 2000), 75-92.

Zohar, D. (2008). Safety climate and beyond: A multi-level multi-climate framework. Safety Science, 46(3), 376-387. https://doi.org/10.1016/j.ssci.2007.03.006

Zohar, D., \& Erev, I. (2006). On the difficulty of promoting workers' safety behaviour: overcoming the underweighting of routine risks. International Journal of Risk Assessment and Management, 7(2), 122-136.

Zohar, D., \& Luria, G. (2005). A multilevel model of safety climate: cross-level relationships between organization and group-level climates. The Journal of Applied Psychology, 90(4), 616-628. https://doi.org/10.1037/0021-9010.90.4.616

Zhang, L., Chen, H., Li, H., Wu, X., \& Skibniewski, M. J. (2018). Perceiving interactions and dynamics of safety leadership in construction projects. Safety Science, 106(May 2017), 6678. https://doi.org/10.1016/j.ssci.2018.03.007

Zohar, D. (2008). Safety climate and beyond: A multi-level multi-climate framework. Safety Science, 46(3), 376-387. https://doi.org/10.1016/j.ssci.2007.03.006 